\title{
Foreign Direct Investment and Trade in the Southern African Development Community
}

\author{
Henri Bezuidenhout ${ }^{1}$ and Wim Naudé
}

October 2008

\begin{abstract}
We use a modified gravity model to estimate the relationship between trade and foreign direct investment (FDI) in the Southern African Development Community (SADC). We find evidence of a significant causal relationship from SADC's exports to inward FDI. Distance (reflecting remoteness and transport costs) and political instability are confirmed to be significant determinants of FDI to SADC. We discern differences in the patterns and determinants of FDI to SADC, whether it is from the USA and UK or from continental Europe. In the case of FDI to SADC from the USA and UK, it is exports from SADC to these countries that are significant, and not imports, while, in the case of continental Europe, both exports and imports are significantly associated with FDI to SADC.
\end{abstract}

Keywords: FDI, SADC, South Africa, exports, gravity model

JEL classification: F21, F14, F23, O16

Copyright (C) UNU-WIDER 2008

${ }^{1}$ EC Afrique, Centurion, South Africa, ${ }^{2}$ UNU-WIDER, Helsinki, Finland

This study has been prepared within the UNU-WIDER project on Southern Engines of Global Growth, co-directed by Amelia U. Santos-Paulino and Guanghua Wan.

UNU-WIDER greatfully acknowledges the financial contributions to the research programme by the governments of Denmark (Royal Ministry of Foreign Affairs), Finland (Ministry for Foreign Affairs), Norway (Royal Ministry of Foreign Affairs), Sweden (Swedish International Development Cooperation Agency-Sida) and the United Kingdom (Department for International Development). 
The World Institute for Development Economics Research (WIDER) was established by the United Nations University (UNU) as its first research and training centre and started work in Helsinki, Finland in 1985. The Institute undertakes applied research and policy analysis on structural changes affecting the developing and transitional economies, provides a forum for the advocacy of policies leading to robust, equitable and environmentally sustainable growth, and promotes capacity strengthening and training in the field of economic and social policy making. Work is carried out by staff researchers and visiting scholars in Helsinki and through networks of collaborating scholars and institutions around the world.

www.wider.unu.edu

publications@wider.unu.edu

UNU World Institute for Development Economics Research (UNU-WIDER)

Katajanokanlaituri 6 B, 00160 Helsinki, Finland

Typescript prepared by Adam Swallow at UNU-WIDER

The views expressed in this publication are those of the author(s). Publication does not imply endorsement by the Institute or the United Nations University, nor by the programme/project sponsors, of any of the views expressed. 


\section{Introduction}

The growing trend towards globalization and regionalization of economies has led to the increased importance of international capital flows. Foreign direct investment (FDI) has become a major source of capital flows in many developing nations. The study of the impacts, causes, and economic relationships of FDI has gained in popularity in the last decade (Naudé and Krugell 2007). There is substantial agreement that FDI can contribute to economic growth and can result in technology transfers to developing countries (Asiedu 2001; Borenstein et al. 1998; Lim 2001; Naudé and Krugell 2007).

In Africa, the potential contribution that FDI can make is significant. The New Partnership for Africa's Development (NEPAD) initiative determined that Africa requires about US\$64 billion annually in capital to be able to generate the growth of 7 per cent per annum that is needed to achieve the millennium development goals (MDGs). Historically, Africa is the region in the world most marginalized in terms of attracting FDI. Sub-Saharan Africa (SSA) only attracted an average of US\$7 billion annually from 1995 to 2001 (US\$2.9 billion if Angola, Nigeria, and South Africa are excluded). This amounts to an average of only 1.5 per cent of total world FDI (Asiedu 2004a; UNCTAD 2005b).

Africa's failure to attract sufficient inflows of FDI is undoubtedly because it is a high risk environment for private capital, due to various institutional and geographical features (Asiedu 2006; Naudé and Krugell 2007), as well as various 'anti-growth policy syndromes' that have depressed investment (Fosu and O'Connell 2006). In the recent past, an increasing number of African countries have embarked on economic reform programmes and initiatives to address these negative features of the policy and institutional environment. Perhaps the most important of these measures are aimed at trade reform, and both unilateral as well as multilateral initiatives have been taken to liberalize trade (Owhoso et al. 2002: 408). The expectation is that trade liberalization will improve the openness of African economies, with benefits to growth coming from more trade (rising exports and the ability to acquire imported inputs for manufacturing production) and FDI (Morriset 2000). In particular, the belief exists that more trade due to trade liberalization will have a determining and positive complementary impact on FDI.1 Greenaway et al. (2007: 206) claim that 'the more open is the trade policy the greater is the economy's gravitational attraction to foreign capital'. They also find evidence from a sample of 77 developing countries over the period 1990-2000 that FDI contributes to growth in open economies, but not closed ones (Greenaway et al. 2007: 208).

In this paper, we investigate the empirical evidence on the link between trade and FDI in Africa. We do so focusing on the Southern African Developing Community (SADC), ${ }^{2}$ a

1 Indeed, despite Africa's poor historical record in terms of attracting FDI, there has been relatively good progress over the past decade or so, with the FDI stock in Africa rising from US\$26 billion in 1990 to US\$187 billion in 2005, with Africa’s share of FDI to developing countries increasing from 4.7 per cent to 6.3 per cent over the same period (UNCTAD 2006a).

2 SADC, established in 1992, consists of 14 countries, including Angola, Botswana, the Democratic Republic of Congo, Lesotho, Madagascar, Malawi, Mauritius, Mozambique, Namibia, South Africa, Swaziland, United Republic of Tanzania, Zambia, and Zimbabwe. South Africa alone accounts for more than 75 per cent of SADC's total GDP. 
multilateral trade initiative, rather than on single countries or on the cross-African case. The reasons for this are twofold. First, SADC represents the most developed region of SSA and is economically the largest contributor to the African economy (SADC 2006). Its relative large (in the African context) internal market can be seen as offering a growing market for foreign investors, as well as a 'springboard' for trade with the rest of SSA (Owhoso et al. 2002: 412). ${ }^{3}$ The SADC aims to establish a Customs Union by 2010. Given the potential for trade diversion due to the relatively large size of one dominant economy (South Africa) (Carrère 2004; Sandrey 2006), understanding the potential impact of trade on FDI might be important for the way in which regional integration is managed. Second, regional integration has been increasing throughout the developing world in recent times (Baldwin 2006). The pertinent question is: Will the resulting growing intra- and inter-regional trade contribute to more FDI? The evidence from SADC could be instructive to other countries and groupings considering trade liberalization and regional integration as strategies to obtain greater FDI.

In the next section, a brief review of the recent literature on FDI and its determinants in Africa is given, with an emphasis on recent discussions on the relationship between trade and FDI. The subsequent section sets out the methodology (an adapted gravity model based on Bos and Van de Laar (2004) and Borrmann et al. (2005)), including a discussion of the data used. The paper goes on to present the results of the empirical study and then offers concluding remarks.

\section{The recent literature}

In this section, we discuss the recent literature on the relationship between trade and FDI, and summarize the findings from recent studies on the determinants and effects of FDI in Africa. We point out that, although important progress has been made in understanding the reasons for the low levels and growth of FDI to Africa, the recent literature has not dealt adequately with the relationship between trade and FDI in Africa.

The relationship between trade and FDI has recently been the subject of some scrutiny in the literature. Mekki (2005) pointed out that the reason for this increasing scrutiny is due to the fact that, traditionally, theories of FDI and trade have different origins and aims. Trade theory tries to explain why countries trade with one another whereas FDI theory tries to explain why firms produce abroad and invest in particular countries. As a consequence, various studies have attempted to integrate FDI into trade theory; for example, Brainard (1993), Dunning (1981), Eaton and Tamura (1994), Fontagné and Pajot (1997), Helpman (1984), Helpman and Krugman (1985), Horstmann and Markusen (1992), Markusen (1983, 1995), and Markusen and Venables (1995). These studies have concluded that, one the one hand, FDI generates complementary trade flows of finished goods, while, on the other hand, they suggested that FDI and trade can act as substitutes for finished goods but be complementary for intermediate goods (Blonigen 2001; Head and Ries 2001; Swenson 2004). Empirical evidence from Tunisia finds that FDI inflows and trade are indeed complementary for the manufacturing sectors of the economy, but are substitutes for some primary sectors (Mekki 2005).

3 It can also be mentioned that the economic literature on SADC as a regional free trade area is relatively small as compared to the much larger economic literature on the West and Central African CFA 'Franc' zones. 
Other empirical studies found that where FDI takes place in the production of a specific good, exports in the same good declined, but exports for intermediate goods used in the production process of the same product rose significantly (Blonigen 2005; Head and Ries 2001; Swenson 2004).

A number of studies also find empirical evidence that FDI and trade are correlated. Jensen (2002) finds that FDI inflows have a positive influence on the technological base of Polish exports. Alguacil and Orts (2002) find a positive relationship between FDI outflows and exports from Spain. Pontes (2004) concludes that, for high levels of trade costs, FDI and trade act as complements and otherwise as substitutes. The OECD (2002) finds that, among their member countries, FDI levels are strongly correlated with trade and trade openness. However, they only treat FDI as a determinant of trade. The OECD (2005) confirms that the long trend among OECD member states is that FDI is becoming more trade intensive as a result of MNEs establishing global production networks and business-to-business value chains. The World Bank (2004) finds that, in general, Asian FDI inflows are increasingly affected by openness to trade and flows to export orientated economies. Fontangé and Pajot (1997) find that, for France, Sweden, the USA, EU, and Japan, the traditional trade theory of FDI acting as a substitute does not hold and that trade and FDI mostly act as complements. Repkine and Walsh (1998) examine the industrial output of Bulgaria, Hungary, Poland, and Romania during the first six years of the post communist era. They found that FDI induced vertical waves of EU orientated output where non-EU output mostly collapsed.

Jun and Singh (1996) argues for bi-directional causality between FDI inflows and exports for developing countries. They conclude that greater export orientation will attract more FDI. Liu et al. (2002) finds empirical bi-directional causality between growth, FDI inflows, and trade in China but only one-way causality to imports. Aizenman and Noy (2005) apply various statistical techniques and find strong bidirectional linkages between FDI flows and trade on an international level, differentiating only between developed and developing countries.

In conclusion it can be said that no clear conclusion is reached on the complementary or substitutionary link between trade and FDI. The literature indicates that the linkage is dependent on the specific case.

As far as SSA is concerned, there have been comparatively few studies on FDI, leading Owhoso et al. (2002: 408) to note that 'the African continent has been ignored in academic studies of FDI'. Although this somewhat of a strong statement (there is a small, but increasing literature on FDI in Africa-see Table 1), it is the case that, with a single exception, not one of the existing studies considered the relationship between trade and FDI in Africa. 4

4 Most studies of FDI in Africa focus on the determinants of FDI to Africa (Ng 2007: 5). 
Table 1 Recent FDI studies on Africa

\begin{tabular}{|c|c|}
\hline Authors & Description of main findings/focus \\
\hline Asiedu (2002) & $\begin{array}{l}\text { The marginal benefit from increased openness to trade is less successful for sub- } \\
\text { Saharan Africa. Africa is therefore different and policies that proved successful } \\
\text { elsewhere might not be equally successful in Africa. }\end{array}$ \\
\hline Asiedu (2004a) & $\begin{array}{l}\text { Sub-Saharan Africa has attracted more FDI due to policy reforms, but has a declining } \\
\text { share of global FDI. }\end{array}$ \\
\hline Asiedu (2004b) & $\begin{array}{l}\text { In order to realize the employment benefits of FDI, sub-Saharan Africa needs to } \\
\text { attract FDI in non-natural resource industries and host countries need to improve their } \\
\text { infrastructure and human capital stocks. }\end{array}$ \\
\hline Asiedu (2006) & $\begin{array}{l}\text { From a study using panel data for } 22 \text { African countries, finds that natural resources } \\
\text { and a large domestic market are important determinants of FDI, and that } \\
\text { macroeconomic policies are also significant. }\end{array}$ \\
\hline $\begin{array}{l}\text { Basu and Srinivasan } \\
(2002)\end{array}$ & $\begin{array}{l}\text { Studies the determinants of FDI in Africa and argue that these can be classified } \\
\text { according to four categories: natural resources, specific locational advantages, } \\
\text { policies towards FDI, and economic reforms. }\end{array}$ \\
\hline Goldstein (2004) & $\begin{array}{l}\text { Political instability (high perceived risk) is a key limitation on FDI to Southern } \\
\text { Africa, despite the region's potential. }\end{array}$ \\
\hline $\begin{array}{l}\text { Jenkins and Thomas } \\
\text { (2002) }\end{array}$ & $\begin{array}{l}\text { Africa's negative international image of political and economic instability has a } \\
\text { severe impact on the whole continent and a concerted effort to improve stability will } \\
\text { also improve FDI inflows. }\end{array}$ \\
\hline Mhlanga (2007) & $\begin{array}{l}\text { The determinants of FDI to SADC are studied using project-level data. It is found that } \\
\text { market size, colonial ties, and proximity of the investing country are the major } \\
\text { determinants of FDI to SADC. }\end{array}$ \\
\hline Morisset (2000) & $\begin{array}{l}\text { Countries with attractive investment environments were able to attract a significant } \\
\text { share of FDI. Therefore, aggressive liberalization and strong economic growth will } \\
\text { lead to an increased level of FDI. }\end{array}$ \\
\hline $\begin{array}{l}\text { Naudé and Krugell } \\
\text { (2007) }\end{array}$ & $\begin{array}{l}\text { Geography does not have a direct influence on FDI flows to Africa and neither } \\
\text { market-seeking nor resource-seeking FDI seems to dominate. Political stability } \\
\text { proved to be a significant determinant of FDI, which indicates that good institutions } \\
\text { are important. }\end{array}$ \\
\hline Ng (2007) & $\begin{array}{l}\text { Studies the link between FDI and productivity in } 14 \text { SSA countries and finds only } \\
\text { limited evidence that FDI inflows contribute to higher productivity in Africa. }\end{array}$ \\
\hline $\begin{array}{l}\text { Seetanah and } \\
\text { Khadaroo (2007) }\end{array}$ & $\begin{array}{l}\text { Investigate the relationship between FDI and growth in the case of } 39 \text { African } \\
\text { countries over the period 1980-2000. They find that FDI has a positive and } \\
\text { significant effect on growth. However, the contribution of FDI to growth is less than } \\
\text { that of domestic private and public investment, and also less than in non-African } \\
\text { countries. }\end{array}$ \\
\hline Te Velde (2002) & $\begin{array}{l}\text { Two issues of concern regarding FDI and Africa are (a) that SSA attracts only a small } \\
\text { share of total FDI flows; and (b) that it is hotly debated whether FDI really leads to } \\
\text { economic and social development in Africa. The focus is on what host countries can } \\
\text { do to influence FDI. }\end{array}$ \\
\hline
\end{tabular}


Some key publications to have focused on FDI in Africa in recent times are summarized in Table 1. From Table 1, it can be seen that the recent literature on FDI in Africa point to the need in African countries for improvements in human capital, infrastructure, political stability and appropriate macro-economic policies.

These studies on FDI to Africa omitted to take into consideration the possible relationship between FDI and trade, the exception being Asiedu (2002) who found that the marginal benefit to FDI from increased openness to trade is not significant for SSA. Apart from this finding, however, it would appear that the relationship between trade and FDI is not well understood in Africa. As has been pointed out, greater openness to trade and rising trade could lead to higher inflows of FDI. For Africa, such a relationship could be important in view of (i) African economies' greater openness to trade, following more and more countries' adoption of trade liberalization programmes and regional integration schemes; and (ii) the greater desire amongst African countries to further regional integration and trade (as seen, for instance, in objectives of the African Union, NEPAD and regional trade agreements such as SADC).

\section{Methodology}

\section{Modelling approach}

We use an adapted gravity model (Bos and Van de Laar 2004). It is derived from Newton's gravity equation that holds that the gravitational pull between two objects is directly and positively related to their mass and the distance between the objects acting as a restraint (Borrmann et al. 2005).

The application in economics implies that an economic flow between two economic entities will depend on their respective economic sizes and the distance between them. Distance can be represented as physical distance, or a psychological restraint or encouragement to do business (Borrmann et al. 2005). For FDI, it can also be stated that gravity, in general, refers to the forces that work to bring actual FDI flows in line with expected FDI flows (Bos and Van de Laar 2004).

The general gravity formula states that the attractive force between objects $i$ and $j$ can be defined as:

$$
F_{i j}=G \frac{M_{i} M_{j}}{D_{i j}^{2}}
$$

where:

- $F_{i j}$ is the attractive force

- $\quad M_{i}$ and $M_{j}$ are the masses

- $D_{i j}$ is the distance between the two objects

- $G$ is a gravitational constant.

If these principles are applied in order to explain FDI in terms of trade it can be written as: 


$$
F D I_{i j}=A_{i j} \frac{X_{i} X_{j}}{D_{i s t}}
$$

where:

- $F D I_{i j}$ is the flow in FDI from home country $i$ to host country $j$

- $\quad X_{i}$ and $X_{j}$ are the respective export totals of $i$ and $j$

- $\quad$ Dist $_{i j}$ is the distance between home country $i$ to host country $j$

- $A_{i j}$ is a constant.

When transformed into a linear equation using logs, it can be written as follows:

$$
\ln F D I_{i j}=\beta_{0}+\beta_{1} \ln X_{i}+\beta_{2} \ln X_{j}-\beta_{3} \ln D i s t_{i j}+\varepsilon_{i j}
$$

(With $\beta_{0}$ a simple constant, $\varepsilon_{i j}$ the error term, $\beta_{1}$ and $\beta_{2}$ are positive.)

The coefficient for the distance term need not be negative. The outcome is reflected in whether distance is a deterrent for FDI or a magnet. Dist $t_{i j}$ represents a vector of variables that represent distance. Theory will also dictate that, in the case of resource seeking FDI, the imports of the home country will determine FDI rather than exports.

During the estimation process, three models are investigated. Each model builds upon, and is an extension of, the previous one. The strategy entails, first, modelling data at an aggregate level and then gradually expanding the model to include individual home and host countries. The first model, Model 1 (covering 1973-2004), a single equation regression, serves as a preliminary investigation into the data and is done at an aggregate level. In Model 2 (covering 1974-2004), Model 1 is expanded to include the export totals of the major trading partners of SADC as separate variables. Model 2 is also a single equation regression. Both Models 1 and 2 give an indication as to the viability and validity of using the adapted gravity approach. With positive results in the first two models, a panel regression is carried out for the SADC countries and their most important trading partners in Model 3 (covering 1989-2004). A Granger causality test is also carried out on the stacked FDI inflow and SADC export variables.

\section{Variables and data}

The variables and data used in Models 1-3 are described in Table 2.

Other variables were also tested but proved not to be significant. They included the Transparency international corruption perception index (Transparency International 2006); the World Bank good governance indicators (World Bank 2006a); trade balances, current account balances, various trade variables, tourist arrivals, number of commodities traded on debts owed from the UNCTAD Handbook of Statistics (UNCTAD 2006b); IMF exchange rates (IMF 2006); and internet connectivity figures from the World Bank development indicators (World Bank 2006b). 
Table 2 List of variables used in final estimations

\begin{tabular}{|c|c|c|}
\hline Variables used & Description & Source \\
\hline \multicolumn{3}{|l|}{ Model 1} \\
\hline SADCFDI & Total FDI inflows to SADC & $\begin{array}{l}\text { UNCTAD FDI online: } \\
\text { www.unctad.org (UNCTAD } \\
\text { 2006a) }\end{array}$ \\
\hline SADCExports & $\begin{array}{l}\text { Total trade exports of SADC to the } \\
\text { developed world }\end{array}$ & $\begin{array}{l}\text { UNCTAD Handbook of Statistics: } \\
\text { www.unctad.org (UNCTAD } \\
\text { 2006b) }\end{array}$ \\
\hline MajorExports & $\begin{array}{l}\text { Total trade of the major developed } \\
\text { countries to the rest of the world }\end{array}$ & $\begin{array}{l}\text { UNCTAD Handbook of Statistics: } \\
\text { www.unctad.org (UNCTAD } \\
\text { 2006b) }\end{array}$ \\
\hline MajorExportstoAfrica & $\begin{array}{l}\text { Total trade of the major developed } \\
\text { countries to Africa }\end{array}$ & $\begin{array}{l}\text { UNCTAD Handbook of Statistics: } \\
\text { www.unctad.org (UNCTAD } \\
\text { 2006b) }\end{array}$ \\
\hline Distance & $\begin{array}{l}\text { Distance from South Africa to the UK is } \\
\text { used because in the aggregate data single } \\
\text { equation distance is a constant. }\end{array}$ & $\begin{array}{l}\text { Distances were calculated with } \\
\text { the www.infoseek.com distance } \\
\text { calculator. It uses coordinates } \\
\text { from the US Geological survey to } \\
\text { calculate distance between two } \\
\text { points on the world globe. }\end{array}$ \\
\hline Dummy90 & $\begin{array}{l}\text { Dummy variable with values of } 1 \text { in } 1979 \text {, } \\
\text { 1985, 1990, and 1994; otherwise 0. These } \\
\text { years were years in which SADC } \\
\text { experienced political turmoil. }\end{array}$ & Own calculations \\
\hline \multicolumn{3}{|l|}{ Model 2} \\
\hline SADCFDI & Total FDI inflows to SADC & $\begin{array}{l}\text { UNCTAD FDI online: } \\
\text { www.unctad.org (UNCTAD } \\
\text { 2006a) }\end{array}$ \\
\hline SADCExports & $\begin{array}{l}\text { Total trade exports of SADC to the } \\
\text { developed world }\end{array}$ & $\begin{array}{l}\text { UNCTAD Handbook of Statistics: } \\
\text { www.unctad.org (UNCTAD } \\
\text { 2006b) }\end{array}$ \\
\hline $\begin{array}{l}\text { USExports, UKExports, } \\
\text { JapanExports }\end{array}$ & $\begin{array}{l}\text { Total trade of the major individual trading } \\
\text { partners (the USA, UK, and Japan) to } \\
\text { Africa }\end{array}$ & $\begin{array}{l}\text { UNCTAD Handbook of Statistics: } \\
\text { www.unctad.org (UNCTAD } \\
\text { 2006b) }\end{array}$ \\
\hline Distance & $\begin{array}{l}\text { Distance from South Africa to the UK is } \\
\text { used because, in the aggregate data single } \\
\text { equation, distance is a constant. }\end{array}$ & $\begin{array}{l}\text { Distances were calculated with } \\
\text { the www.infoseek.com distance } \\
\text { calculator. It uses coordinates } \\
\text { from the US Geological survey to } \\
\text { calculate distance between two } \\
\text { points on the world globe. }\end{array}$ \\
\hline \multicolumn{3}{|l|}{ Model 3} \\
\hline Dummy76 & $\begin{array}{l}\text { Dummy variable with values of } 1 \text { in } 1976 \text {, } \\
\text { 1979, 1985, 1990, and 1994; otherwise } 0 . \\
\text { These years were years in which SADC } \\
\text { experienced political turmoil. }\end{array}$ & Own calculations \\
\hline FDIinflows & $\begin{array}{l}\text { Stacked variable of the FDI inflows to the } \\
\text { respective SADC countries }\end{array}$ & $\begin{array}{l}\text { UNCTAD FDI online: } \\
\text { www.unctad.org (UNCTAD } \\
\text { 2006a) }\end{array}$ \\
\hline ExportsSADC & $\begin{array}{l}\text { Stacked variable of the value of } \\
\text { merchandise exports of the respective } \\
\text { SADC countries }\end{array}$ & $\begin{array}{l}\text { UNCTAD Handbook of Statistics: } \\
\text { www.unctad.org (UNCTAD } \\
\text { 2006b) }\end{array}$ \\
\hline
\end{tabular}




\begin{tabular}{|l|l|l|}
\hline $\begin{array}{l}\text { ExportsUS, ExportsUK, } \\
\text { ExportsGermany, } \\
\text { ExportsFrance, ExportsItaly, } \\
\text { ExportsJapan }\end{array}$ & $\begin{array}{l}\text { Total trade of the individual trading } \\
\text { partners to Africa }\end{array}$ & $\begin{array}{l}\text { UNCTAD Handbook of Statistics: } \\
\text { www.unctad.org (UNCTAD } \\
\text { 2006b) }\end{array}$ \\
\hline $\begin{array}{l}\text { DistanceUS, DistanceUK, } \\
\text { DistanceGermany, } \\
\text { DistanceFrance, DiatanceItaly, } \\
\text { DistanceJapan }\end{array}$ & $\begin{array}{l}\text { A stacked variable of distance from the } \\
\text { respective SADC countries to their } \\
\text { individual trading partners the USA, UK, } \\
\text { Germany, France, Italy, and Japan. }\end{array}$ & $\begin{array}{l}\text { Distances were calculated with } \\
\text { the www.infoseek.com distance } \\
\text { calculator. It uses coordinates } \\
\text { from the US Geological survey to } \\
\text { calculate distance between two } \\
\text { points on the world globe. }\end{array}$ \\
\hline Dummypol & $\begin{array}{l}\text { Stacked dummy variable that represents } \\
\text { political instability and natural disasters in } \\
\text { the respective SADC countries. }\end{array}$ & $\begin{array}{l}\text { Crudely constructed by using the } \\
\text { brief historical overviews of the } \\
\text { individual SADC countries and } \\
\text { years of instability as given in the } \\
\text { CIA Factbook (CIA 2006) and the } \\
\text { Encyclopaedia Britannica } \\
\text { (Britannica 2006). }\end{array}$ \\
\hline
\end{tabular}

The equations in Model 1 and Model 2 are estimated for aggregate SADC, while the panel in Model 3 contains the stacked data for individual SADC countries. SADC consists of Angola, Botswana, the Democratic Republic of Congo, Lesotho, Madagascar, Malawi, Mauritius, Mozambique, Namibia, South Africa, Swaziland, Tanzania, Zambia, and Zimbabwe (SADC 2006). Six more countries could conceivably be included in SADC, in the long term. They are Burundi, Comoros, Kenya, Rwanda, Seychelles, and Uganda. For the purposes of this paper, they are included as their trade and geographic locations are completely intertwined with SADC. FDIs from South Africa in other SADC countries are not taken into consideration. Although increasingly important for SADC, outward FDI from South Africa, China, and India in Africa is a relatively recent phenomenon (Henley et al. 2007: 6). The scope of the study covers 1989 to 2004 and thus the relationship with these countries cannot as yet be adequately empirically investigated.

For Model 3 distance is calculated from the individual SADC countries' capitals to the trading partners' capitals.

\section{Empirical results}

In this section, the results of the empirical analysis are presented, discussed and interpreted. The results were obtained as outlined in the previous section and consist of the individual results of the three specified models.

\section{Model 1}

Table 3 shows the final results of Model 1. Total exports of the developed world are limited to their exports to Africa only. A dummy variable (Dummy90) is introduced. Dummy90 is 0 except for $1979,1985,1990$, and 1994 , where it is 1 . These years were of great consequence for the SADC region, as they represent (i) the end of the Rhodesian conflict in 1979; (ii) the debt freeze of South Africa in 1985; (iii) significant political changes announced in South Africa, Tanzania, Mozambique, and Kenya in 
1990; and the changes in South Africa in 1994. It explains why the variable is significant at the 5 per cent level. The explanatory variables are 'lagged' for one period and finally an AR(2) term proves to be highly significant at the 5 and 1 per cent levels. All these changes bring about significant change in the estimation results. The 'Total exports of the developed world' variable is the only variable that is insignificant even at the 10 per cent level.

Table 3 Model 1 results

\begin{tabular}{lccc}
\hline $\begin{array}{l}\text { Dependent variable: LOG(SADCFDI) } \\
\text { Method: Least squares (sample: 1973-2004) }\end{array}$ & & & \\
Variable & Coefficient & t-statistic & Prob. \\
\hline LOG(SADCExports(Lag1)) & 3.972 & 5.064 & $0.000^{*}$ \\
LOG(ExportstoAfrica(Lag1)) & -1.353 & -1.482 & 0.151 \\
LOG(Distance) & -1.867 & -2.023 & $0.053^{*}$ \\
Dummy90 & -0.543 & -2.486 & $0.020^{*}$ \\
AR(2) & 0.635 & 5.641 & $0.000^{*}$ \\
& & & \\
\hline $\mathrm{R}^{2}$ & & & 0.837 \\
Adjusted R & & & 0.811 \\
Akaike info criterion & & & 2.043 \\
Schwarz criterion & & & 2.276 \\
Durbin-Watson stat. & & & 1.604 \\
& & &
\end{tabular}

Because Model 1 is a preliminary investigation, no further investigation or a more indepth statistical analysis is carried out. The fact that the SADC export variable is significant at the 1 per cent level, and the distance variable is also significant at the 10 per cent level, clearly indicates that relationships as set out in the adapted gravity model do exist within the data. This warrants further investigation.

\section{Model 2}

In Table 4, the results are shown for Model 2. Total export of the trading partners is limited to exports to Africa only, as suggested by Model 1. A dummy variable that is an expansion of dumm1990 from Model 1 is also included. The years of 1977 and 1983 are added as having a value of 1 to 1979, 1985, 1990, and 1994 to take into account (i) the Angolan and Rhodesian conflicts of 1977; (ii) the aftermath of the Soweto riots of 1976; and (iii) the severe droughts and food shortages that occurred in the region in 1983. All variables except EU exports and distance, which once again form the constant term, are significant at the 1 per cent level. Due some missing values, the sample size is reduced to 1974 to 2004. 


\begin{tabular}{|c|c|c|c|}
\hline \multicolumn{4}{|c|}{ Dependent variable: LOG(SADCFDI) } \\
\hline \multicolumn{4}{|c|}{ Method: Least squares (sample: 1974-2004) } \\
\hline Variable & Coefficient & t-Statistic & Prob. \\
\hline LOG(SADCExports) & 2.702 & 7.601 & $0.000 *$ \\
\hline LOG(USexports) & 3.096 & 5.531 & $0.000^{*}$ \\
\hline LOG(UKexports) & -2.402 & -2.541 & $0.018^{*}$ \\
\hline LOG(Japanexports) & -2.483 & -6.502 & $0.000 *$ \\
\hline LOG(Distance) & 0.056 & 0.179 & 0.860 \\
\hline Dummy76 & -1.003 & -14.324 & $0.000^{*}$ \\
\hline $\mathrm{R}^{2}$ & & & $0.965 *$ \\
\hline Adjusted $\mathrm{R}^{2}$ & & & $0.958 *$ \\
\hline Akaike info criterion & & & $0.528 *$ \\
\hline Schwarz criterion & & & $0.808^{*}$ \\
\hline Durbin-Watson stat & & & 1.607 \\
\hline
\end{tabular}

All test results indicate a satisfactory fit but, due to fears of multicollinearity and unit roots, further investigation into the accuracy of the equation is needed. The total exports variables are all subject to concurrent global economic trends and could lead to multicollinearity, and also unit roots in the residuals, that could bias the estimation results. Table 5 gives the test results for the model and its residuals. It should be noted that all tests confirm a good fit.

Model 2 finds a statistically significant relationship between FDI inflows to SADC and trade. Specifically, the results show that a complementary relationship exists between exports from SADC and FDI, and between imports from the USA (USExports) and FDI to SADC. The negative coefficients on LOG(UKexports) and LOG(Japanexports) would suggest, at this stage, substitution between SADC imports from these countries and FDI inflows. Political instability in 1976 appears to be significant and has a negative impact on FDI inflows. In Table 4, the coefficient on the distance variable is, however-contrary to expectations—insignificant.

As mentioned in previous sections, there are some questions as to whether trade causes FDI or whether FDI causes trade. Most evidence for developed countries suggests that FDI causes trade, with little FDI being caused by trade. Therefore, it is pertinent to examine the causality between trade and FDI in SADC before doing the panel estimations. Table 6 shows the results of a Granger causality test that was done on the stacked series of FDI inflows to the individual SADC countries and the stacked value of merchandise exports. The test was repeated with various lagged options but always gave 
the same result. The test indicates that, in the specific case of the 20 countries included in the analysis, exports from SADC (Granger) cause FDI to SADC.

Table 5 Model 2: regression diagnostics

\begin{tabular}{llc}
\hline Summary of test results & & \\
\hline Ramsey RESET test: & F-statistic & 0.048 \\
& Log likelihood ratio & 0.063 \\
\hline White heteroskedasticity test: & F-statistic & 0.912 \\
& Obs*R $^{2}$ & 20.085 \\
\hline Breusch-Godfrey Serial Correlation LM test: & F-statistic & 0.062 \\
& Obs*R $^{2}$ & 0.168 \\
\hline ARCH test: & F-statistic & 0.893 \\
& Obs*R ${ }^{2}$ & 0.929 \\
\hline Normality tests: & Jarque-Bera & 0.781 \\
& Jarque-Bera probability & 0.677 \\
& Skewness & 0.080 \\
& Kurtosis & 2.226 \\
\hline Unit root tests: & Augmented Dickey-Fuller test statistic & -4.844 \\
& Augmented Dickey-Fuller test probability & 0.001 \\
& Phillips-Perron test statistic & -4.844 \\
& Phillips-Perron test probability & 0.001 \\
\hline Forecast tests: & Mean Absolute Error & 0.268 \\
& Mean Absolute Percentage Error & 4.360 \\
\hline
\end{tabular}

Table 6 Causality test for FDI and exports in SADC

\begin{tabular}{lcc}
\hline Pairwise Granger causality tests & Sample: 1970-2005 & \\
Lags: $\mathbf{1}$ & Obs & $\mathbf{5 2 3}$ \\
Null hypothesis: & F-Statistic & Probability \\
\hline ExportsSADC does not Granger Cause FDIinflows & 37.199 & 0.000 \\
FDIinflows does not Granger Cause ExportsSADC & 1.530 & 0.217 \\
& & \\
GDP does not Granger Cause FDIinflows & 42.747 & 0.000 \\
FDIinflows does not Granger Cause GDP & 14.946 & 0.000 \\
& & \\
GDP does not Granger Cause ExportsSADC & 15.4581 & 0.000 \\
ExportsSADC does not Granger Cause GDP & 28.5061 & 0.000 \\
\hline
\end{tabular}




\section{Model 3}

Model 3 consists of six panel estimations using the gravity specification. Estimations were done for a different trading partner, while the panel represents the variables for the 20 SADC countries. Table 7 shows the final estimation results for the panel estimations of the 20 SADC countries with the six major trading partners.

In the case of the USA and UK, all variables are significant at the 1 per cent level except the total trade of the USA/UK with Africa. These are also the only two equations where the constant was significant. For France and Germany, all variables were significant at the 1 per cent level. For France, however, an AR (1) term was also significant. Italy mostly shares results with France and Germany but the total export of Italy variable is only just not significant at the 10 per cent level. In the equation for Japan, only the SADC exports and the political stability dummy variable are statistically significant.

SADC exports are significant throughout the estimations and this confirms the result of the Granger causality test. It should be noted that the coefficient of SADC exports for all the estimations is nearly on a 1 to 1 basis. This implies that, for every 1 per cent increase in SADC exports, there is an almost 1 per cent increase in FDI.

The large negative and mostly significant coefficients on distance and 'Dummypol' for most equations indicates, first, that the SADC countries are geographically very distant to their trading partners and that, second, perceived political instability matters for FDI.

Table 7 Model 3 results

\section{Dependent variable: LOG(FDIinflows)}

Method: Panel GMM EGLS (cross-section weights) (sample: 1989-2004)

\begin{tabular}{lcccccc}
\multicolumn{1}{c}{ Variable } & $*$ USA & $*$ UK & $*$ Germany & *France & *Italy & $*$ Japan \\
\hline Constant & $58.59(3.55)$ & $36.67(2.2)$ & & & & \\
LOG(ExportsSADC) & $0.88(11.04)$ & $0.96(8.66)$ & $0.91(17.47)$ & $0.88(12.57)$ & $0.92(14.66)$ & $0.91(12.35)$ \\
LOG(Export*) & $-0.13(-0.20)$ & $-0.82(-0.69)$ & $1.12(2.59)$ & $1.36(2.37)$ & $0.93(1.65)$ & $-0.45(-0.65)$ \\
LOG(Distance*) & $-6.21(-4.26)$ & $-3.45(-3.67)$ & $-1.32(-3.04)$ & $-1.62(-2.66)$ & $-1.16(-2.04)$ & $0.25(0.38)$ \\
Dummypol & $-3.77(-6.47)$ & $-4.22(-4.79)$ & $-3.39(-11.96)$ & $-3.2(-7.3)$ & $-2.63(-7.7)$ & $-3.24(-5.65)$ \\
AR 1 Term & $0.27(3.63)$ & $0.315(4.27)$ & & $0.33(6.14)$ & $0.36(5.11)$ & $0.36(5.09)$ \\
\hline
\end{tabular}

\begin{tabular}{|c|c|c|c|c|c|c|}
\hline \multicolumn{7}{|c|}{ Weighted statistics } \\
\hline$\overline{\mathrm{R}^{2}}$ & 0.599 & 0.453 & 0.625 & 0.720 & 0.854 & 0.712 \\
\hline Adjusted R-squared & 0.591 & 0.443 & 0.621 & 0.716 & 0.852 & 0.707 \\
\hline Durbin-Watson stat & 1.936 & 1.951 & 1.329 & 1.976 & 2.029 & 1.975 \\
\hline J-statistic & 0.076 & 0.000 & 6.584 & 3.032 & 3.382 & 0.618 \\
\hline \multicolumn{7}{|c|}{ Unweighted statistics } \\
\hline$\overline{\mathrm{R}^{2}}$ & 0.529 & 0.327 & 0.571 & 0.698 & na & 0.687 \\
\hline Sum $^{2}$ Residual & 696.427 & 976.573 & 632.501 & 463.594 & na & 481.931 \\
\hline Durbin-Watson stat. & 1.859 & 1.869 & 1.232 & 1.977 & na & 1.951 \\
\hline
\end{tabular}

Note: t-statistic in parenthesis. 
The overall measures of fit are mixed and fluctuate between rather mediocre fits for the USA and the UK to overall good fits for Germany, France, and Italy. Panel unit root tests indicate that no unit root is present but normality tests indicate that normality cannot be assumed for the residuals. This is attributed to the severe fluctuations in the data, which coincides with periods of political instability.

In periods of substantial fluctuations, there is possible over-or-under estimation of the actual value. This is more significant for the figures of Burundi than for the other countries. This problem could be addressed by amending the dummy variable. It is, however, not advisable because the fluctuations should be seen as the inability of the gravity specification to capture all the relevant variables that explain FDI inflows or the inability of a dummy variable to explain the effects of political instability completely. Other variables outside the scope of the gravity specification might be effective in explaining the fluctuation observed in the residuals. Country specific evaluation might deliver other results because they are not obtained as the overall error that includes the joint series of country residuals. In future research, the specification can be opened up to include other variables that might explain the fluctuations more clearly. In a country specific evaluation, other results might also be obtained. Both of these suggestions fall outside the scope of this paper.

The final conclusion from Table 7 is that the general trend in FDI inflows is significantly explained in the estimation by SADC exports, distance, and political instability. The insignificance of US, UK and Japanese exports to SADC suggests a possible lack of complementarities between SADC imports from, and FDI inflows from these countries, in contrast to the complementarities in both exports and imports to and from Germany, France, and Italy.

\section{Concluding remarks}

In a recent assessment of policies needed to lift African countries out of their poverty trap, Sachs et al. (2004: 150) placed a high priority on regional integration, stating that 'Regional integration will raise the interest of potential foreign investors by increasing the scope of the market.' In this paper, we focused on the SADC and asked whether, in these countries, a relationship exists between trade and FDI. In so doing, the contribution of this paper was threefold. First, we contributed to the relatively small, but growing literature on FDI in Africa. Second, we contributed towards understanding the relationship between trade and FDI in Africa, which has so far been neglected in the literature. Third, our results are of interest to countries in Africa considering regional integration as a strategy to raise economic growth through greater openness to trade.

Using an adapted gravity model, we found that there is indeed a significant causal and positive relationship between FDI inflows to SADC and SADC exports. Distance and political instability are also significant determinants with a negative relation to FDI. The export variables for home countries left mixed results with the USA, UK, and Japan having insignificant and negative coefficients. Germany, France, and Italy had positive significant coefficients but insignificant constant values. The results for these mainland European countries indicate a complementary role between home exports and host FDI inflows. 
From these results the following policy recommendations can be made. First, trade liberalization remains important in Southern Africa for attracting more FDI through its beneficial impacts on exports from the region (Edwards and Alves 2006; Mengistae and Patillo 2004). Second, further regional integration within SADC needs to ensure that trade diversion losses from traditional trading partners such as the EU and the USA be minimized; however, given the general strong relationship between exports and FDI, further regional integration might increase the 'proximity' of countries to their export destination markets, especially in the case of the many landlocked countries in SADC. Indeed, this could also benefit landlocked countries such as Burundi, Rwanda, and Uganda, which are currently not members. Third, growing trade within SADC as a result of regional integration might lead to growing investment from South Africa in the region, given the country's proximity to its other SADC partners. The country is already the third largest single investor in other SADC countries in dollar values (Mhlanga 2007: 9). Finally, greater efforts will need to be made within SADC to limit the negative impacts and 'neighbourhood effects' that political instability can exert on FDI. The region's apparent inability to contribute solutions to the ongoing crisis in Zimbabwe could ultimately be costing the whole region in terms of FDI.

\section{References}

Aizenman, J. and I. Noy (2005) 'FDI and Trade - Two-way Linkages?', National Bureau of Economic Research (NBER), Working Paper 11403, June.

Alguacil, M.T. and V. Orts (2002) 'A Multivariate Cointegrated Model Testing for Temporal Causality between Exports and Outward Foreign Investment: The Spanish Case', Applied Economics and Fundacion de Estudios de Economia Aplicada, EEE50.

Asiedu, E. (2002) 'On the Determinants of Foreign Direct Investment to Developing Countries: Is Africa Different?’ World Development, 30 (1): 107-119.

Asiedu, E. (2004a) 'Policy Reform and Foreign Direct Investment in Africa: Absolute Progress but Relative Decline’, Development Policy Review, 22 (1): 41-8.

Asiedu, E. (2004b) 'The Determinants of Employed of Affiliates of US Multinational Enterprises in Africa’, Development Policy Review, 22 (4): 371-9.

Asiedu, E. (2006) 'Foreign Direct Investment in Africa: The Role of Natural Resources, Market Size, Government Policy, Institutions and Political Stability’, World Economy, 29 (1): 63-77.

Baldwin, R.E. (2006) 'Multilateralising Regionalism: Spaghetti Bowls as Building Blocks on the Path to Global Free Trade’, World Economy, 29 (11): 1451-518.

Basu, A. and K. Srinivasan (2002) 'Foreign Direct Investment in Africa: Some Case Studies’, IMF Working Paper WP/02/6 (Washington, DC: IMF).

Blonigen, B. A. (2005) 'A Review of the Empirical Literature on FDI Determinants', National Bureau of Economic Research (NBER), Working Paper 11299, April.

Blonigen, B.A. (2001) 'In Search of Substitution between Foreign Production and Exports', Journal of International Economics, 53 (1): 81-104. 
Borenstein, E., J. de Gregorio, J.-W. Lee (1998) 'How Does Foreign Direct Investment Affect Economic Growth?’, Journal of International Economics, 45: 115-35.

Borrmann, C., R. Jungnickel and D. Keller (2005) 'What Gravity Models Can Tell Us about the Position of German FDI in Central and Eastern Europe', Hamburg Institute of International Economics (HWWA), Discussion Paper 328, August.

Bos, J.W.B. and M. Van De Laar (2004) 'Explaining Foreign Direct Investment in Central Europe: An Extended Gravity Approach', Research Memoranda 041, Maastricht: METEOR, Maastricht Research School of Economics of Technology and Organization.

Brainard, S. L. (1993) 'A Simple Theory of Multinational Corporations and Trade with a Trade-off between Proximity and Concentration', National Bureau of Economic Research (NBER), Working Paper 4269, February.

Carrère, C. (2004) 'African Regional Agreements: Impact on Trade with or without Currency Unions’, Journal of African Economies, 31 (2): 199-239.

CIA (Central Intelligence Agency) (2006) World Factbook (Available at https://www.cia.gov/cia/publications/factbook/index.html) (accessed 23 Nov. 2006).

Dunning, P. (1981) International Production and the Multinational Enterprise (London: George Allen \& Unwin).

Eaton, J. and A. Tamura (1994) 'Bilateralism and Regionalism in Japanese and US Trade and Direct Foreign Investment Patterns', Journal of the Japanese and International Economies, 8: 478- 10.

Edwards, L. and P. Alves (2006) 'South Africa's Export Performance: Determinants of Export Supply’, South African Journal of Economics, 74 (3): 473-500.

Encyclopedia Britannica (2006) (Available at http://www.britannica.com) (accessed 22 Nov. 2006).

Fontagné, L and M. Pajot (1997) 'How Foreign Direct Investment Affects International Trade and Competitiveness: An Empirical Assessment', CEPII, Working document 97-17.

Fosu, A.K. and S. A. O’Connell (2006) 'Explaining African Economic Growth: The Role of Anti-growth Syndromes', in Annual Bank Conference on Development Economics 2006 (Washington, DC: World Bank).

Goldstein, A. (2004) Regional Integration, FDI and Competitiveness in Southern Africa (Paris: OECD).

Greenaway, D., D. Sapsford and S. Pfaffenzeller (2007) 'Foreign Direct Investment, Economic Performance and Trade Liberalization’, World Economy, 30 (2): 197-210.

Head, K., and J. Ries (2001) 'Overseas Investment and Firm Exports', Review of International Economics, 9 (1): 108-22.

Helpman, E. (1984) 'A Simple Theory of International Trade with Multinational Corporations', Journal of Political Economy, 92 (3): 451-71, June. 
Helpman, E. and P. R. Krugman (1985) 'Market Structure and Foreign Trade', in Increasing Returns, Imperfect Competition and the International Economy (Cambridge, MA: MIT Press).

Henley, J., S. Kratzch, M. Külür and T. Tandogan (2007) 'Foreign Direct Investment from China, India and South Africa in Sub-Saharan Africa: A New or Old Phenomenon?', paper presented at the UNU-WIDER Conference on 'Southern Engines of Global Growth: China, India, Brazil and South Africa', Helsinki, Finland, 8 September.

Horstmann, I.J. and J. R. Markusen (1992) 'Endogenous Market Structure in International Trade’, Journal of Economics, 32: 109-29.

IMF (2006) 'The World Economic Outlook for September 2006' (Available at http://www.imf.org/external/pubs/ft/weo/2006/02/data/index.aspx) (accessed 8 Nov. 2006).

Infoplease Distance Calculator (2006) (Available at http://www.infoplease.com/atlas/calculate-distance.html) (accessed 22 Nov. 2006).

Jenkins, C. and L. Thomas (2002) 'Foreign Direct Investment in Southern Africa: Determinants, Characteristics and Implications for Economic Growth and Poverty Alleviation', Mimeo (CSAE/Oxford and CREFSA, London School of Economics).

Jensen, C. (2002) 'Foreign Direct Investment, Industrial Restructuring and the Upgrading of Polish Exports', Applied Economics, 34: 207-17.

Jun, K.W. and H. Singh (1996) 'The Determinants of Foreign Direct Investment in Developing Countries’, UNCTAD: Transnational Corporations, 5: 67-105.

Lim, E. (2001) 'Determinants of, and the Relation between, Foreign Direct Investment and Growth: A Summary of Recent Literature’, IMF Working Paper WP/01/175.

Liu, X., P. Burridge, P. J. N. and Sinclair (2002) 'Relationships between Economic Growth, Foreign Direct Investment and Trade: Evidence from China', Applied Economics, 34 (11): 1433-40.

Markusen, J. R. (1983) 'Factor Movements and Commodity Trade as Complements', Journal of International Economics, 14: 341-56.

Markusen, J. R. (1995) 'The Boundaries of Multinational Enterprises and the Theory of International Trade', Journal of Economic Perspectives, 9: 169-89.

Markusen, J. R. and A. J. Venables (1995) 'Multinational Firms and the New Trade Theory’, NBER Working Paper 5036 (Cambridge, MA: NBER).

Mekki, R. (2005) 'The Impact of Foreign Direct Investment on Trade: Evidence from Tunisia', paper presented at 4th Annual Conference of the European Economics and Finance Society on 'Economic and Financial Issues in an Enlarged Europe', Coimbra, Portugal, 19 May.

Mengistae, T. C. and Pattillo (2004) 'Export Orientation and Productivity in SubSaharan Africa, IMF Staff Papers, 51 (2): 327-53.

Mhlanga, N. (2007) 'Understanding Foreign Direct Investments to the Southern African Development Community (SADC): An Analysis Based on Project-Level Data', 
paper presented at the UNU-WIDER Conference on 'Southern Engines of Global Growth: China, India, Brazil and South Africa’, Helsinki, Finland, 8 September.

Morisset, J. (2000) 'Foreign Direct Investment in Africa: Policies also Matter', UNCTAD: Transnational Corporations, 9 (2): 107-25.

Naudé, W. A. and W. F. Krugell (2007) 'Investigating Geography and Institutions as Determinants of Foreign Direct Investment in Africa using Panel Data', Applied Economics, 39 (10-12): 1223-34.

Ng, T. H. (2007) 'Foreign Direct Investment and Productivity: Evidence from SubSaharan Africa’, Unpublished paper (Vienna: UNIDO).

OECD (2002) Foreign Direct Investment for Development (Paris: OECD).

OECD (2005) International Investment Perspectives (Paris: OECD).

Owhoso, V., K. C. Gleason, I. Mathur and C. Malgwi (2002) 'Entering the Last Frontier: Expansion by US Multinationals to Africa', International Business Review, 407-3.

Pontes, J. P. (2004) 'A Theory of the Relationship between Foreign Direct Investment and Trade', Economics Bulletin, 6 (2): 1-8.

Repkine, A. and P. P. Walsh (1998) 'European Trade and Foreign Direct Investment Ushaping Industrial Output in Central and Eastern Europe: Theory and Evidence', IMF Working Paper WP/98/150.

Sachs, J. D., J. W. McArthur, G. Schmidt-Traub M. Kruk, C. Bahadur, M. Faye and G. McCord (2004) 'Ending Africa’s Poverty Trap’, Brookings Papers on Economic Activity, 1: 117-240.

SADC (Southern African Development Community) (2006) (Available at http://www.sadc.int) (accessed 5 Sept. 2006).

Sandrey, R. (2006) 'Trade Creation and Trade Diversion Resulting from SACU Trading Agreements', tralac Working Paper 11/2006 (Available at www.tralac.org).

Seetanah, B. and A. J. Khadaroo (2007) 'Foreign Direct Investment And Growth: New Evidences from Sub- Saharan African countries', paper presented at the Centre for the Study of African Economies Conference on 'Economic Development in Africa', Oxford, 20 March.

Swenson, D. L. (2004) 'Foreign Investment and Mediation of Trade Flows', Review of International Economics, 12 (4): 609-29.

Te Velde, D. W. (2002) Foreign Direct Investment for Development: Policy Challenges for Sub-Saharan African Countries (London: Overseas Development Institute).

Transparency International (2006) (Available at http://www.transparency.org) (accessed 24 Nov. 2006).

UNCTAD (2005a) Economic Development in Africa: Rethinking the Role of Foreign Direct Investment, UNCTAD/GDS/AFRICA/2005/1 (Geneva: UNCTAD). 
UNCTAD (2005b) World Investment Report, FDI Indicators (Available at http://www.unctad.org/Templates/WebFlyer.asp?intItemID=3489andlang=1) (Accessed 8 May 2006).

UNCTAD (2006a) FDI online (Available at http://stats.unctad.org/fdi/ReportFolders/ReportFolders.aspx?CS_referer=andCS_Ch osenLang=en) (accessed 12 Nov. 2006).

UNCTAD (2006b) Handbook of Statistics (Available at http://www.unctad.org/Templates/Page.asp?intItemID=1890andlang=1) (accessed 12 Nov. 2006).

World Bank (2004) 'Foreign Direct Investment in Developing Asia', Asian Development Outlook Part 3 (Washington, DC: World Bank).

World Bank (2006a) 'Good Governance Indicators' (Available at http://www.worldbank.org/wbi/governance/) (accessed 8 Nov. 2006).

World Bank (2006b) 'World Development Indicators' (Available at http://web.worldbank.org/WBSITE/EXTERNAL/DATASTATISTICS/0,,contentMD K:20899413 menuPK:232599 pagePK:64133150 piPK:64133175 theSitePK:2394 19,00.html) (accessed 8 Nov. 2006). 